\title{
Are There Early Clinical Factors to Decide Early Surgical Management for Secondary Chylothorax? A Review of 32 Cases
}

\author{
Addas Ramzi, Thumerel Matthieu, Jougon Jacques, Delcambre Frédéric, Velly Jean-Francois
}

Department of Thoracic Surgery, Haut-Lévêque Hospital, Bordeaux, France.

Email: ramziaddas@yahoo.com, Jacques.jougon@chu-bordeaux.fr, Jean-francois.velly@chu-bordeaux.fr

Received February $24^{\text {th }}, 2013$; revised March $30^{\text {th }}, 2013$; accepted April $10^{\text {th }}, 2013$

Copyright (C) 2013 Addas Ramzi et al. This is an open access article distributed under the Creative Commons Attribution License, which permits unrestricted use, distribution, and reproduction in any medium, provided the original work is properly cited.

\begin{abstract}
Background: Chylothorax may be primary (spontaneous) or secondary and more often arising as a postoperative complication of thoracic surgery. It occurs when the thoracic duct or its lymphatic tributaries become blocked or perforated or divided resulting in a chylous pleural effusion. Loss of chyle leads to nutritional deficiencies, dehydration, ionic perturbation and lymphocytes leaks thus increasing the vulnerability for infections and respiratory dysfunction. It is a life-threatening complication increasing the postoperative hospital stay. Management of chylothorax is firstly medical which leads to the cessation of leaks in most of the cases. Surgical treatment by thoracic duct ligation is sometimes necessary after failure of medical treatment. The appropriate time for surgical treatment is a subject of controversy. Methods: Reviewing a series of patients treated between 2000 to 2010 in a single center with the same protocol management, the aim of the study was to identify early clinical variables allowing early surgical treatment in postoperative chylothorax. Results: Thirty-two patients were identified in the study period. There were 21 males (65.6\%) and 11 females (34.4\%) with a mean age of 55.7 years (range from 9 to 79 years) (Table 1). Twenty-two patients (68.75\%) had chylothorax after a surgical intervention, seven patients (21.8\%) had chylothorax due to medical causes and three patients (9.3\%) after chest trauma. Thirty-eight percent of patients treated conservatively were after lung cancer resection and $35 \%$ of patients treated surgically where after esophageal resection. Chylothorax was stopped in 33\% of patients after lymphangiography. Cumulative leak per day was $1007 \mathrm{ml} /$ day for operated patients and $397 \mathrm{ml} /$ day for patient treated conservatively. Esophageal resection surgery and the amount of fluid leak were the two factors founded to be associated for the decision of an earlier surgical treatment. Conclusion: Chylothorax arising after esophageal resection with a flow rate of leak of more than $500 \mathrm{ml} /$ day should be proposed to an earlier surgical treatment. Lymphangiography remains a key stone assessment with a double aim diagnostic and therapeutic in chyle leakage.
\end{abstract}

Keywords: Chylothorax; Thoracic Duct; Morbidity

\section{Introduction}

Chylothorax occurs when the thoracic duct or its lymphatic tributaries become blocked or perforated or divided resulting in a chylous pleural effusion. In clinical practice, the most frequent cause of chylothorax is traumatic (post-surgical) and classified as secondary chylothorax. Spontaneous cause is called primary chylothorax and is caused by malignant lymph node diseases or congenital lymphatic diseases. Loss of chyle leads to nutritional deficiencies, dehydration, ionic perturbation and lymphocyte leaks thus increasing the vulnerability for infections and finally respiratory dysfunction by metabolic or mechanical mechanisms. Management of secondary chylothorax is a subject of controversy between medical or conservative treatment and surgical treatment.

As a general rule, surgical treatment is considered after failure of conservative treatment for several days. However, the period of medical treatment is not clearly identified and there is no evidence based medicine trials that have been founded for this management. Reviewing our series of patients treated for chylothorax, we want to identify early clinical variables allowing earlier surgical treatment rather than extended conservative medical treatment in case of secondary chylothorax. 
Table 1. Patients data.

\begin{tabular}{cc}
\hline Category & Number of patients \\
\hline Sex & Male 21 (65.6\%) \\
Female $11(34.4 \%)$ \\
From 9 to 79 years \\
(average 55.7 y) \\
From 28.4 to 88 Kg \\
(average 65.26 Kg) \\
lung cancers & $7(21.8 \%)$ \\
Oesophageal cancers & $5(15.6 \%)$ \\
Other cancers & $8(25 \%)$ \\
Diabetes & $3(9.3 \%)$ \\
Hypertension & $11(34.3 \%)$ \\
Tabagism & $7(21.8 \%)$ \\
Alcoolism & $2(6.25 \%)$ \\
Hypercholesterolemia & $6(18.75 \%)$ \\
Cardiac diseases & $6(18.75 \%)$ \\
HIV & $2(6.25 \%)$ \\
Pulmonary hypertension & $1(3.1 \%)$ \\
Sarcoidosis & $1(3.1 \%)$ \\
Pulmonary lymphangiomyomatosis & $1(3.1 \%)$ \\
Cardiac surgery & $2(6.25 \%)$ \\
\hline
\end{tabular}

\section{Patients and Methods}

A retrospective analysis of all patients treated between the years 2000 and 2010 for chylothorax in our thoracic surgery department, Haut-lêvèque Hospital, Bordeaux, France (a tertiary center of thoracic surgery) was performed. The patient files were coded on Excel (Microsoft) and analysed. The aim of the study was to identify early clinical variables allowing earlier surgical treatment rather than delayed surgery after time consuming medical conservative treatment. During the study period, management of chylothorax was performed with the following method: Diagnosis of chylothorax was firstly suspected in case of large amount of pleural leak or milky appearence of pleural effusion and confirmed by triglyceride level $>110 \mathrm{mg} / \mathrm{dl}$ in doubted cases. When the pleural fluid triglyceride level is $>110 \mathrm{mg} / \mathrm{dL}$, there is $<1 \%$ chance of it not being chylous, and pleural fluid with a triglyceride value of $<50 \mathrm{mg} / \mathrm{dL}$ has no more than a $5 \%$ chance of being chylous. When the triglyceride level is between 55 and $110 \mathrm{mg} / \mathrm{dL}$, a lipoprotein analysis is indicated to detect chylomicrons. In case of primary (spontaneous) chlothorax non-invasive assessment (thoracoabdominal CT scan, thoracocentesis, PET scan if needed) was first done. Later on, a video-assisted thoracoscopy was indicated for diagnostic purposes (allowing pleural and mediastinal exploration and biopsy) or for treatment by talc poudrage and drainage by two chest tubes. In case of secondary chylothorax a protocol of management was applied consisting of three steps. The first step was a conservative medical treatment with two subsequent managments. The first one consisted of thoracic drain if not done and low-fat oral diet in case of pleural fluid leakage less than $500 \mathrm{ml} / \mathrm{day}$. The second was applied in case of pleural fluid leakeage of more than $500 \mathrm{ml} /$ day and consisted of total bowel rest and parenteral nutrition with administration of a somatostatine analogue, during one week. Pleural fluid loss was compensated volume per volume with two-thirds $0.9 \%$ normal saline and one-third 5\% albumine. Lipid soluble vitamins were added as well in association with one ampul of vitamin $\mathrm{K}$ per week. In the second step, lymphangiography was performed in certain cases. Lymphangiography was planned after the 8th day of conservative treatment if pleural fluid leakage per day is not decreased. Lymphangiography was considered as a diagnostic as well as a therapeutic procedure. The last step of treatment was realized more than 5 days after lymphangiography as the therapeutic effect of lymphangiography may be delayed. The last step was the surgical treatment. A blunt mediastinal or elective ligation of the thoracic duct was performed through right sided video-assisted thoracoscopy or right sided thoracotomy. A fat rich drink was routinely given an hour before the operation to enhance the visualization of the thoracic duct leak. The efficiency of the treatment applied was consisted by clinical assessment including vital signs at least three times daily, blood tests and chest X-rays every two days and the measurement of daily fluid loss graphically presented by a histogram. To check predisposing factors for early surgical treatment, patients were classified in two group: group 1, patients treated surgically after failure of medical conservative treatment (Table 2) and group 2, patients who were treated medically with successful results (Table 3).

\section{Results}

During the last ten years there were 32 patients diagnosed as having chylothorax, either admitted with chylothorax or chylothorax occurring after a planned surgery. There were 21 males (65.6\%) and 11 females (34.4\%) with a mean age of 55.7 years (range from 9 to 79 years).Twenty-two of the patients (68.75\%) had chylothorax after a surgical intervention, seven patients (21.8\%) had chylothorax due to medical causes and three patients (9.3\%) after chest trauma. The causes of primary chylothorax were retroviral HIV infection in 2 cases, Paget disease in 1 case, cystic lymphangioma in 1 case, metastatic testicular carcinoma in 1 case, mediastinal fibrosis in 1 case, and associated with myasthenia gravis in one case. Chylothorax was resolved by medical treat- 
Table 2. Patients treated surgically after the diagnosis of chylothorax.

\begin{tabular}{|c|c|c|c|c|c|c|c|c|}
\hline Patient & $\begin{array}{c}\text { Age } \\
\text { (years) }\end{array}$ & Sex & $\begin{array}{c}\text { Weight } \\
\text { (Kg) }\end{array}$ & $\begin{array}{c}\text { Cause of } \\
\text { chylothorax }\end{array}$ & Treatment & $\begin{array}{c}\text { Pleural fluid } \\
\text { loss } \\
\text { (mL/day) }\end{array}$ & $\begin{array}{c}\text { Days of } \\
\text { hospitalization }\end{array}$ & Follow up \\
\hline 1 & $68 \mathrm{y}$ & Male & 59 & $\begin{array}{l}\text { Right superior } \\
\text { lobectomy }\end{array}$ & $\begin{array}{l}\text { TD ligation } \\
\text { by } \\
\text { thoracotomy }\end{array}$ & 930 & 37 & Ok \\
\hline 2 & $47 y$ & Male & 65 & $\begin{array}{l}\text { Lymph node } \\
\text { dissection }\end{array}$ & $\begin{array}{l}\text { TD ligation } \\
\text { by VATS }\end{array}$ & 1000 & 9 & Ok \\
\hline 3 & $53 \mathrm{y}$ & Female & 54 & $\begin{array}{l}\text { Left superior } \\
\text { lobectomy } \\
\text { (Pancoast ) }\end{array}$ & $\begin{array}{l}\text { TD ligation } \\
\text { (twice ) }\end{array}$ & 1500 & 40 & Ok \\
\hline 4 & $67 \mathrm{y}$ & Female & 50 & $\begin{array}{l}\text { Right inferior } \\
\text { lobectomy }\end{array}$ & TD ligation & 1750 & 27 & Ok \\
\hline 5 & $56 y$ & Male & 66 & Oesophag-ectomy & TD ligation & 2000 & 29 & Ok \\
\hline 6 & $52 y$ & Female & 47 & ideopathic & $\begin{array}{l}\text { TD ligation } \\
\text { (twice ) }\end{array}$ & 244 & 64 & Ok \\
\hline 7 & $79 \mathrm{y}$ & Male & 81 & Oesopag-ectomy & $\begin{array}{l}\text { TD ligation } \\
\text { (failed) } \\
\text { lymphography }\end{array}$ & 560 & 56 & Ok \\
\hline 8 & $77 \mathrm{y}$ & Male & 79 & Oesophag-ectomy & $\begin{array}{l}\text { TD ligation } \\
\text { (three times) }\end{array}$ & 865 & 48 & Ok \\
\hline 9 & $70 \mathrm{y}$ & Male & 83 & Oesophag-ectomy & TD ligation & 1000 & 23 & Ok \\
\hline 10 & $25 \mathrm{y}$ & Male & 60 & $\begin{array}{c}\text { Compression of } \\
\text { TD by } \\
\text { mediastinal } \\
\text { fibrosis }\end{array}$ & TD ligation & 750 & 24 & Ok \\
\hline 11 & $57 \mathrm{y}$ & Male & 81 & $\begin{array}{c}\text { Post-op } \\
\text { Coarctation of } \\
\text { aorta }\end{array}$ & $\begin{array}{l}\text { TD ligation } \\
\text { (failed) } \\
\text { Medical } \\
\text { treatment }\end{array}$ & 400 & 40 & Ok \\
\hline 12 & $55 \mathrm{y}$ & Male & 67 & Oesophag-ectomy & $\begin{array}{l}\text { TD ligation } \\
\text { (failed) } \\
\text { Medical } \\
\text { treatment }\end{array}$ & 1500 & 50 & Ok \\
\hline 13 & $34 \mathrm{y}$ & Female & 52 & $\begin{array}{l}\text { Carotid to } \\
\text { sub-clavian } \\
\text { bypass }\end{array}$ & TD ligation & 350 & 47 & Ok \\
\hline 14 & $77 \mathrm{y}$ & Male & 84 & Thoracic trauma & TD ligation & 1250 & 10 & Ok \\
\hline Average & $58.35 \mathrm{y}$ & $\begin{array}{c}\text { Male } 10 \\
(71.4 \%) \\
\text { Female } 4 \\
(28.6 \%)\end{array}$ & 66.28 & & & $\begin{array}{l}1007.5 \\
\mathrm{~mL} / \text { day }\end{array}$ & 36 & \\
\hline
\end{tabular}

TD: Thoracic Duct.

ment in 1 case, by VATS with talcage in 4 cases and by thoracic duct ligation in 2 cases (mediastinal fibrosis and myasthenia associated case). Post traumatic chylothorax occurred in 3 cases. Leak cessation was obtained after medical treatment in 2 cases and duct ligation after lymphography was necessary in 1 case. Chylothorax occurred after a planned surgical intervention in 22 cases. Thoracic duct ligation was performed in 14 patients. The leak was stopped after surgery in 11 cases and surgery failed in 3 cases. The time spent before surgery varied between one week to one month in some cases. The average flow rate of leak for patients treated surgically was $1007 \mathrm{~mL} /$ day and for patients treated medically was 397 $\mathrm{mL} /$ day. Lymphography was performed in 9 cases, leading to leak cessation in 3 cases (33\%) (Table 4).In our study post-operative complications associated with chylothorax include three cases of post-operative pneumopathy (9.3\%), four cases of anemia (12.5\%), two cases of atrial fibrillation (6.25\%). Other complications include vocal cord paralysis, diaphragmatic paralysis, urinary 
Table 3. Patients treated conservatively (medically) after the diagnosis of chylothorax.

\begin{tabular}{|c|c|c|c|c|c|c|c|}
\hline Patient & Age (years) & Sex & Weight (Kg) & Cause of chylothorax & $\begin{array}{c}\text { Pleural fluid } \\
\text { loss } \\
\text { (mL/day) }\end{array}$ & $\begin{array}{c}\begin{array}{c}\text { Days of } \\
\text { hospitalization } \\
\text { (Days) }\end{array} \\
\end{array}$ & Follow up \\
\hline 1 & $69 \mathrm{y}$ & Male & 65 & Chest trauma & 75 & 12 & Ok \\
\hline 2 & 38 y & Male & 70 & $\begin{array}{l}\text { Pleural effusion (HIV } \\
\text { positive) }\end{array}$ & 225 & 6 & Ok \\
\hline 3 & $66 \mathrm{y}$ & Male & 54 & mediastinoscopy & 390 & 29 & Ok \\
\hline 4 & $71 \mathrm{y}$ & Female & 70 & Chest trauma & 570 & 14 & Ok \\
\hline 5 & $45 \mathrm{y}$ & Male & 74 & $\begin{array}{l}\text { Cervico-manubriotomy for } \\
\text { a neurogenic tumor }\end{array}$ & 270 & 11 & Ok \\
\hline 6 & $53 \mathrm{y}$ & Female & 53 & $\begin{array}{c}\text { Cervical cystic } \\
\text { lymphangioma } \\
\text { (spontaneous appearance of } \\
\text { pleural effusion) }\end{array}$ & 100 & 3 & Ok \\
\hline 7 & $61 \mathrm{y}$ & Male & 62 & $\begin{array}{l}\text { Right lung superior } \\
\text { lobectomy }\end{array}$ & 450 & 16 & Ok \\
\hline 8 & $57 \mathrm{y}$ & Female & 49 & $\begin{array}{l}\text { Cervicotomy for a left } \\
\text { desmoid tumor }\end{array}$ & 340 & 16 & Ok \\
\hline 9 & $72 \mathrm{y}$ & Male & 85 & Right lung bi-lobectomy & 1000 & 27 & Ok \\
\hline 10 & $44 \mathrm{y}$ & Female & 51 & $\begin{array}{l}\text { Left lung inferior } \\
\text { lobectomy }\end{array}$ & 520 & 9 & Ok \\
\hline 11 & $75 \mathrm{y}$ & Male & 69 & Right lung bi-lobectomy & 460 & 22 & $\mathrm{Ok}$ \\
\hline 12 & $49 \mathrm{y}$ & Female & 57 & $\begin{array}{l}\text { Bilateral lung transplant for } \\
\text { lymphangio-myomatosis }\end{array}$ & 590 & 37 & Ok \\
\hline 13 & $41 \mathrm{y}$ & Male & 76 & $\begin{array}{l}\text { Right lung superior } \\
\text { lobectomy }\end{array}$ & 180 & 12 & Ok \\
\hline Average & $57 y$ & $\begin{array}{c}\text { Male } 8 \\
(61.5 \%) \\
\text { Female } 5 \\
(38.5 \%)\end{array}$ & 64.2 & & $\begin{array}{l}397.69 \\
\text { (mL/day) }\end{array}$ & 16.46 & \\
\hline
\end{tabular}

infection and an edematous reaction at the level of a patients feet after lymphography (Table 5). Mean hospital stay was 36 days for group1 (patients treated surgically) and 16.46 days for group 2 (patients treated conservatively). We do not find significant difference between the two groups concerning patient characteristics except for the average of fluid loss that seems to be higher in the group of patients treated surgically (Figure 1).

\section{Discussion}

Our results are not so different than those reported in other series. According to our results, it seems that an earlier surgical treatment should be applied when the flow rate of the leakage is more than $500 \mathrm{ml} /$ day after the 5th postoperative day.

Shimizu et al. [1] had reported that early surgical intervention may be indicated if chest tube drainage is more than $500 \mathrm{~mL}$ during the first 24 hours after complete oral intake cessation and total parenteral nutrition.
Dugue et al. [2] have been reported the cut-off of 10 $\mathrm{ml} / \mathrm{kg}$ at day 5 after the onset of chylothorax for the decision between conservative and surgical treatment in a series of esophageal resection. This strategy should be adapted to the type of surgery.

Esophageal resection is perhaps the most common iatrogenic cause of chylothorax, and an incidence of $4 \%$ has been noted in the literature [3].

Chylothorax arising after esophageal resection for carcinoma is more often due to the perforation of the thoracic duct itself and not one of its tributaries. In that case the flow rate of leakage is high (more than $500 \mathrm{ml} /$ day) and medical treatment would fail and earlier surgical treatment should be applied.

In our experience, since the last 5 years we have been adopted new technology of tissue fusion (Ligasure) for esophageal resection. We have noticed reduction of operative time and incidence of chylothorax due to fusion of tissue fat pad in the infra-mediastinal space just above the diaphragm against the aorta. 
Table 4. Patients who had lymphography after the diagnosis of chylothorax.

\begin{tabular}{|c|c|c|c|c|c|c|c|}
\hline Patient & Age (years) & Sex & Weight (Kg) & Cause of chylothorax & $\begin{array}{c}\text { Date of } \\
\text { lymphography }\end{array}$ & $\begin{array}{c}\text { Result of } \\
\text { lymphography }\end{array}$ & $\begin{array}{c}\text { Days of } \\
\text { hopt }\end{array}$ \\
\hline 1 & $68 \mathrm{y}$ & Male & 59 & $\begin{array}{l}\text { Right lung superior } \\
\text { lobectomy }\end{array}$ & $\begin{array}{l}\text { Day } 13 \text { post } \\
\text { lobectomy }\end{array}$ & $\begin{array}{l}\text { Chylous pleural } \\
\text { fluid continue } \\
\text { after the } \\
\text { lymphography }\end{array}$ & 37 \\
\hline 2 & $67 \mathrm{y}$ & Female & 50 & $\begin{array}{l}\text { Right lung inferior } \\
\text { lobectomy }\end{array}$ & $\begin{array}{l}\text { Day } 12 \text { post } \\
\text { lobectomy }\end{array}$ & No improvement & 27 \\
\hline 3 & $52 \mathrm{y}$ & Female & 61 & $\begin{array}{c}\text { Cardiopulmonary } \\
\text { transplantation } \\
\text { (sarcoidosis and } \\
\text { pulmonary hypertension) }\end{array}$ & $\begin{array}{l}\text { One month } \\
\text { after the } \\
\text { transplantation }\end{array}$ & $\begin{array}{l}\text { Chylothorax was } \\
\text { stopped after the } \\
\text { lymphography }\end{array}$ & 50 \\
\hline 4 & $56 \mathrm{y}$ & Male & 66 & Post oesophagectomy & $\begin{array}{c}\text { Day } 20 \text { post } \\
\text { oesophag-ectomy }\end{array}$ & No improvement & 29 \\
\hline 5 & $9 y$ & Male & 28.4 & $\begin{array}{l}\text { Post bi-cavo bi-pulmonary } \\
\text { anastomosis for a } \\
\text { congenital heart disease }\end{array}$ & $\begin{array}{l}\text { Three weeks } \\
\text { after his } \\
\text { operation }\end{array}$ & $\begin{array}{c}\text { Chylothorax was } \\
\text { stopped few days } \\
\text { after } \\
\text { lymphography }\end{array}$ & 50 \\
\hline 6 & $79 \mathrm{y}$ & Male & 80 & Post oesophagectomy & $\begin{array}{l}\text { Day } 13 \text { after TD } \\
\text { ligation }\end{array}$ & $\begin{array}{l}\text { Chylothorax was } \\
\text { stopped after } \\
\text { lymphography }\end{array}$ & 56 \\
\hline 7 & $57 \mathrm{y}$ & Male & 81 & $\begin{array}{l}\text { Post an operation for } \\
\text { coarctation of aorta }\end{array}$ & $\begin{array}{l}\text { Three weeks } \\
\text { post-op }\end{array}$ & No improvement & 40 \\
\hline 8 & $55 \mathrm{y}$ & Male & 67 & Post oesophagectomy & $\begin{array}{l}\text { One month post } \\
\text { oesophag-ectomy }\end{array}$ & No improvement & 50 \\
\hline 9 & $77 \mathrm{y}$ & Male & 84 & Chest trauma & $\begin{array}{c}\text { One month after } \\
\text { the diagnosis of } \\
\text { chylothorax } \\
\text { Was followed in } \\
\text { OPC } \\
\text { Hospitalized in } \\
\text { our service for } \\
\text { TD ligation }\end{array}$ & No improvement & 10 \\
\hline
\end{tabular}

Prophylactic ligation of the thoracic duct during oesophageal surgery has been recommended by some surgeons to prevent chylous fistula [4]. Some advocate routine ligation of the thoracic duct, especially with tumors of the midoesophagus [5]. The incidence of post-oesophagectomy chylothorax reduced from 9 to 2.1\% when elective ligation of the major thoracic duct was performed in a series of 255 patients [5].Concerning chylothorax after pleuropulmonary surgery we reported 8 cases of chylothorax after lobectomies for lung cancers with radical lymphadenectomy (2 left lobectomies and 6 right lobectomies). A conservative treatment was sufficient in 5 cases and surgery was necessary in 3 cases. Chylothorax occurring after lung cancer surgery is usually due to the perforation of one of the tributaries of thoracic duct. Conservative treatment with or without lymphangiography is usually sufficient except after pneumonectomy. In the literature there are a few cases of chylothorax after operations for diseases of the pleura. Endoscopic pleurolysis has frequently caused chylotho- rax.

Thoracoplasty, lobectomy and pneumonectomy are also common causes. Kuntz had reported some instances of chylothorax after segmental resection as well as one case after pulmonary decortication [6].

Chylothorax after cardiovascular operations was noted in three patients in our series. The first was after a coarctation of aorta operation, the patient had a thoracic duct ligation with no improvements and the chylothorax was stopped after restarting the conservative treatment after the failure of the operation. The second patient was a 9 year-old boy that had a cardiac operation due to a congenital anomaly, chylothorax was stopped few days after the performance of lymphangiography. The third case was after an operation of carotid subclavian bypass, for this patient chylothorax was stopped after ligation of the thoracic duct. Chylothorax has been reported after surgical treatment of the following cardiovascular malformations: tetralogy of Fallot [7-9], patent ductus arteriosus [10-12], tricuspid atresia [13], coarctation of the 
Table 5. Other postoperative complications associated with chylothorax.

\begin{tabular}{cc}
\hline Postoperative complication & Number of patients \\
\hline Anemia & $4(12.5 \%)$ \\
Postoperative pneumopathy & $3(9.4 \%)$ \\
Auricular fibrillation & $2(6.25 \%)$ \\
Urinary infection & $1(3 \%)$ \\
Vocal cord paralysis & $1(3 \%)$ \\
Diaphragmatic paralysis & $1(3 \%)$ \\
Edematous reaction of the feet after & $1(3 \%)$ \\
lymphography & \\
\hline
\end{tabular}

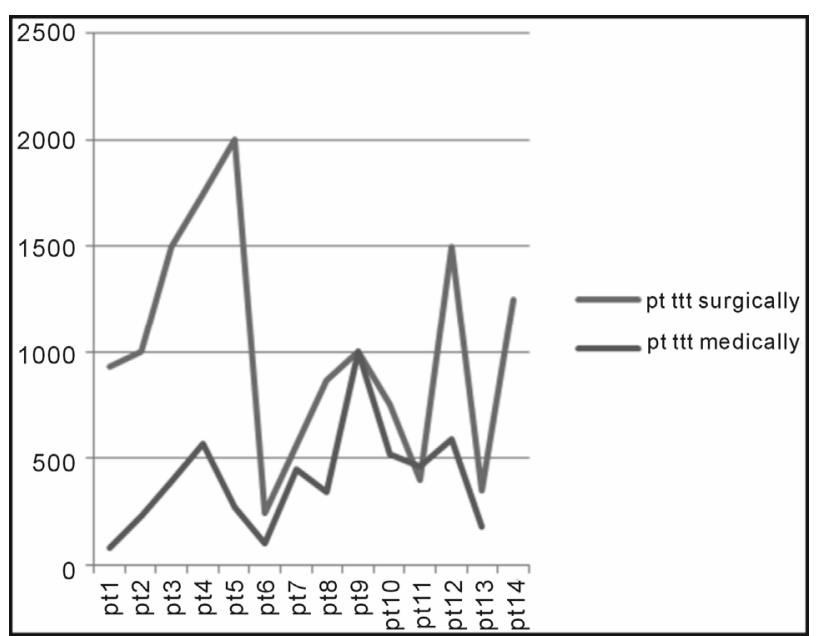

Figure 1. Comparison between the amount of pleural fluid loss for patients treated surgically and patients treated medically after the diagnosis of chylothorax.

aorta [14], and several complex malformations.

Chylothorax occurred in two cases after transplantation in our series. The first was after double lung transplantation for lymphangioleiomyomatosis in one case. Diagnosis of chylothorax was done on the 7th post-operative day and the leak was stopped after 7 days of medical treatment. Lymphangioleiomyomatosis is an uncommon progressive thoracic pathology in females of childbearing age. It results in nodular and diffuse interstitial proliferation of the smooth muscle in the lungs, lymph nodes, and thoracic duct. Two-thirds of the patients have chylous pleural effusion [15-17]. Chylothorax due to lymphangioleiomyomatosis was described in 6 cases of the 44 patients (13\%) transplanted in the French experience (Reynaud-Gaubert) [18]. The second case was a chylothorax after heart-lung transplantation for sarcoidosis and pulmonary hypertension. This patient was also treated medicaly and chylothorax was stopped totally few days after performing lymphography. There are not much studies in the literature studing chylothorax after lung transplantation. Shitrit D [19] had noted that chylothorax can present late after lung transplantation and that conservative treatment should be considered in pateints with good nutritional status.

Chylothorax after mediastinal surgery had also reported in our study in one case after a diagnostic mediastinoscopy. Chylothorax was stopped after conservative treatment. Chylothorax occurs relatively often after operations for cysts and tumors of the mediastinum. There are frequent observations of chylothorax after the removal of mediastinal or cervicomediastinal lymphangioma. The statistical incidence of such a complication in this group is about 1.8 percent [20]. Gruwez [21] has reported a case of chylothorax after removal of a mediastinal goiter. Chylothorax after cervical surgery was observed in three cases in our study. The first was chylothorax after cervical dissection after the diagnosis of thyroid cancer. The second was after a cervical surgery for a desmoid tumor and the third for a neurogenic tumor. The first patient was treated by thoracic duct ligation, the second and the third patients were treated conservatively. Extensive neck dissections may give rise to postoperative chylothorax [22-24]. The possibility of injury to the thoracic duct is always present during operations for neoplasms of the cervical area, especially in operations necessitating removal of the jugular vein and the sternocleidomastoid muscle.

Thambo et al. [25] advocate lymphangiography as essential examination before surgical treatment of chylothorax for two reasons. First, it allows visualization of the thoracic duct anatomy as we should bear in mind that variation in the anatomy of the thoracic duct is common. Second, we believe in therapeutic role of lymphangiography by sclerotic effects of the thoracic duct vessels induced by ethiodized oil, a contrast agent used to opacify lymphatic network.

As the reason that surgical treatment should not be performed immediately after lymphography, but it should be performed around five days after lymphography.

This effect has been also reported by Matsumoto et al. [26] for various chyle leakages, in 8 of the 9 patients (89\%) that Matsumoto included in his study, lymphatic leakage was stopped after lymphangiography and surgical re-intervention was avoided. However, lymphangiography is a time consuming assessment requiring great skill and patience, and is performing by only one radiologist in our radiology department. That explains why in our series lymphangiography was performed in only 9 cases of the 22 post-operative cases depending on availability of the radiologist. It is a safe assessment and more useful than lymphoscintigraphy.

\section{Conclusion}

Although many cases of chylothorax can be cured with a 
conservative managment, early surgical intervention may be indicated if chest tube drainage is more than $500 \mathrm{~mL}$ during the first 24 hours after complete oral intake cessation and total parenteral nutrition.

\section{REFERENCES}

[1] K. Shimizu, J. Yoshida, M. Nishimura, K. Takamochi, R. Nakahara and K. Nagai, "Treatment Strategy for Chylothorax after Pulmonary Resection and Lymph Node,” The Journal of Thoracic and Cardiovascular Surgery, Vol. 124, No. 3, 2002, pp. 499-502. doi:10.1067/mtc.2002.124386

[2] L. Dugue, A. Sauvanet, O. Farges, A. Goharin, J. Le Mee and J. Belghiti, "Output of Chyle as an Indicator of Treatment for Chylothorax Complicating Oesophagectomy,” British Journal of Surgery, Vol. 85, No. 8, 1998, pp. 1147-1149. doi:10.1046/j.1365-2168.1998.00819.x

[3] A. McWilliams and E. Gabbay, "Chylothorax Occurring 23 Years Post-Irradiation: Literature Review and Management Strategies,” Respirology, Vol. 5, No. 3, 2000, pp. 301-303. doi:10.1046/j.1440-1843.2000.00263.x

[4] C. Bolger, T. Walsh, W. Tanner and T. Hennessy, "Chylothorax after Oesophagectomy,” British Journal of Surgery, Vol. 78, No. 5, 1991, pp. 587-588. doi:10.1002/bjs.1800780521

[5] D. Dougenis, W. S. Walker, E. W. Cameron and P. R. Walbaum, "Management of Chylothorax Complicating Extensive Esophageal Resection," Surgery Gynecology \& Obstetrics, Vol. 174, No. 6, 1992, pp. 501-506.

[6] E. Kuntz, "Eine Ubersicht uber das Schrifttum von 1945 bis 1965 mit 297 Fallen und Bericht uber 3 eigene Beobachtungen," Beiträge zur Klinik und Erforschung der Tuberkulose und der Lungenkrankheiten, Vol. 133, No. 2, 1966, pp. 98-125. doi:10.1007/BF02112815

[7] H. B. Shumacker Jr. and T. C. Moore, "Surgical ManAgement of Traumatic Chylothorax,” Surgery Gynecology \& Obstetrics, Vol. 93, No. 1, 1951, pp. 46-50.

[8] A. L. Mcgregor, "Injuries to the Large Lymph-Ducts," British Journal of Surgery, Vol. 40, No. 164, 1953, pp. 569574. doi:10.1002/bjs.18004016408

[9] T. G. Baffes and W. J. Potts, "Postoperative Chylothorax,” Annals of Surgery, Vol. 139, No. 4, 1954, pp. 501505. doi:10.1097/00000658-195404000-00016

[10] M. S. Gotsman, "Chylothorax after Closure of a Patent Ductus Arteriosus,” Thorax, Vol. 21, No. 2, 1966, pp. 129131. doi:10.1136/thx.21.2.129

[11] J. D. Hardy, G. R. Walker Jr. and V. C. Deguzman, “Thoracic Duct Fistula in Infant. Blue Dye Localization and Operative Closure,” JAMA, Vol. 182, No. 2, 1962, pp. 187188. doi:10.1001/jama.1962.03050410083021

[12] J. C. Jones, “Twenty-Five Years' Experience with the Surgery of Patent Ductus Arteriosus," The Journal of Thoracic and Cardiovascular Surgery, Vol. 50, 1965, pp. 149-165.

[13] J. V. Maloney Jr. and F. C. Spencer, "The Nonoperative Treatment of Traumatic Chylothorax,” Surgery, Vol. 40, No. 1, 1956, pp. 121-128.
[14] C. B. Higgins and D. G. Mulder, "Chylothorax after SurGery for Congenital Heart Disease," The Journal of Thoracic and Cardiovascular Surgery, Vol. 61, No. 3, 1971, pp. 411-418.

[15] C. B. Carrington, D. W. Cugell, E. A. Gaensler, A. Marks, R. A. Redding, J. T. Schaaf and A. Tomasian, "Lymphangioleiomyomatosis. Physiologic-Pathologic-Radio-Logic Correlations," The American Review of Respiratory Diseases, Vol. 116, No. 6, 1977, pp. 977-995.

[16] B. Corrin, A. A. Liebow and P. J. Friedman, "Pulmonary Lymphangiomyomatosis, a Review," American Journal of Pathology, Vol. 79, No. 2, 1975, pp. 348-382.

[17] T. Urban, R. Lazor, J. Lacronique, M. Murris, S. Labrune, D.Valeyre and J. F. Cordier, "Study and Research Group of Pulmonary Orphan Disease,” Medicine (Baltimore), Vol. 78, No. 5, 1999, pp. 321-337.

[18] M. Reynaud-Gaubert, J. F. Mornex, H. Mal, M. Treihaud, C. Dromer, S. Quetant, F. Leroy-Ladurie, R. Guillemein, F. Philit, G. Dauriat, D. Grenet and M. Stern, "Lung Transplantation for Lymphangiomyomatosis: The French Experience," Transplantation, Vol. 86, No. 4, 2008, pp. 515-520. doi:10.1097/TP.0b013e31817c15df

[19] D. Shitrit, G. Izbicki, D. Starobin, D. Aravot and M. R. Kramer, "Late-Onset Chylothorax after Heart-Lung Transplantation," The Annals of Thoracic Surgery, Vol. 75, No. 1, 2003, pp. 285-286. doi:10.1016/S0003-4975(02)04172-3

[20] P. G. Cevese, R. Vecchioni, D. F. D’Amico, C. Cordiano, R. Biasiato, G. Favia and G. A. Farello, "Postoperative Chylothorax. Six Cases in 2500 Operations, with a Survey of the World Literature,” The Journal of Thoracic and Cardiovascular Surgery, Vol. 69, No. 6, 1975, pp. 966-971.

[21] J. Gruwez, A. Lacquet, G. Cardoen, C. Dive and A. Baert, "Considerations on Chylothorax," Acta Chirurgica Belgica, Vol. 66, No. 1, 1967, pp. 64-78.

[22] L. A. Brewer 3rd, "Surgical Management of Lesions of the Thoracic Duct; the Technic and Indications for Retroperitoneal Anastomosis of the Thoracic Duct to the Hemiazygos Vein,” The American Journal of Surgery, Vol. 90, No. 2, 1955, pp. 210-227.

[23] G. S. Fitz-Hugh and R. Cowgill, "Chylous Fistula,” Archives of Otolaryngology, Vol. 91, No. 6, 1970, pp. 543547. doi:10.1001/archotol.1970.00770040773010

[24] E. L. Frazell, C. C. Harrold Jr. and L. Rasmussen, "Bilateral Chylothorax; an Unusual Complication of Radical Neck Dissection with Recovery,” Annals of Surgery, Vol. 134, No. 1, 1951, pp. 135-137. doi:10.1097/00000658-195107000-00018

[25] J. B. Thambo, M. Jimenez, J. Jougon, V. Latrabe, R. Giraradot, D. Crepin, N. Laborde, X. Roques and A. Choussat, "Diagnostic and Therapeutic Value of Lymphography in Persistent Postoperative Chylothorax," Archives des Maladies du Coeur et des Vaisseaux, Vol. 97, No. 5, 2004, pp. 546-548.

[26] T. Matsumoto, T. Yamagami, T. Kato, T. Hirota, R. Yoshimatsu, T. Masunami and T. Nishimura, "The EffecTiveness of Lymphography as a Treatment Method for Various Chyle Leakages,” British Journal of Radiology, Vol. 82, No. 976, 2009, pp. 286-290. doi:10.1259/bjr/64849421 